\title{
THE VIDEO LEARNING EFFECTS OF CIVIC EDUCATION TO STUDENTS KNOWLEDGE ABOUT STATE IN SATU ATAP LONTAR JUNIOR HIGH SCHOOL
}

\author{
${ }^{1}$ Angela Efianda, ${ }^{2}$ Vina Mahdalena, ${ }^{3}$ Lusia Handayani \\ ${ }^{1}$ Department of Political Science, \\ ${ }^{2,3}$ Department of Communication Science, \\ Universitas Pembangunan Nasional Veteran Jakarta, Indonesia
}

\begin{abstract}
This research purposed to analyze the effect of video learning of civic education about state which was manipulated by experiment group (audio visual method use video) and control group (conventional method use teacher) to gain students knowledge. The samples of the study were fourty students in Satu Atap Lontar Junior High School who had not implemented the audio visual (video) learning method. This study applied an experimental design with pretest and posttest design. The results score of experiment group pretest means are 5.35 and posttest means are 6.2. The increase of knowledge generated from this method was $8.8 \%$, after that, we do the paired $t$ test and did not show any significance at all. Different results were obtained by the control group, with a pretest means are 7.65 and posttest means are 9.1. The increased of this method was $19.7 \%$, after that, we do the paired $t$ test and show the real significant with $\mathrm{p}<.05$. The conclusion that learning by conventional methods can not be completely replaced by audio visual methods. However, they can be collaborated into effective learning methods to increase students knowledge of state in rural schools, especially Satu Atap Lontar Junior High School.
\end{abstract}

Keywords: civic education, knowledge, state, video 


\section{INTRODUCTION}

The history of the journey of Indonesian people since the Proclamation of August $17^{\text {th }}$ 1945 untill now shows a fairly high dynamics. The implementation of state governance for more than 73 years is still tinged with various political turmoil colored by group or group interests, and among them has developed into a security disturbance that has an influence on national stability. Differences in understanding and political clash at the level of elites as a result of differences in vision in the management of the state system, easily penetrated into the lives of lower-level people (grass root), thus negatively affecting the level of social relations of the community.

Learning from the long history of Indonesia starting from the growing awareness of the nation to entering the era of the struggle for independence, all Indonesian people should realize that only by unity, that is prioritizing mutual will and for a common goal, this nation succeeded in realizing its ideals of independence and freedom from shackles of colonial power. Therefore, with this awareness, the Indonesian people in fighting for their national ideals must always uphold a sense of unity and be willing to sacrifice for their nation and country.

National awareness pioneered by Indonesia's young generation in its era, which later gave birth to and encouraged the realization of the ideals of Indonesian independence, basically grew and developed by the encouragement of the common will of all components of society (the Indonesian Nation) that differed in ethnicity, religion, culture, which spread throughout the archipelago. The aim is none other than realizing the desire to build a large new community in a unified whole, namely the Indonesian nation.

Through smart and wise thinking, and based on a deep sensitivity of conscience, the founding fathers succeeded in elevating the values contained in the life of the Indonesian people and the teachings of the ancestors, so that the national values were formulated concretely and agreed to be used as a basis and guidance in the formation and implementation of the state (national system building), as well as in establishing national character building as capital in managing the life of the community, nation and state.

The dynamics of community life, nation and state are increasingly important to observe. Because of the magnitude of the influence of culture, outlook on life, political systems, values and economic systems that develop in the governance of world social life. It should be realized, that the influence of global life is not fully in accordance with the values of the Indonesian people. Even slowly but surely the entry of new values can actually diminish the sense of nationality, especially in the lives of the young generation of the Indonesian nation. This influence is difficult to prevent as a result of the advancement of Information and Communication Technology (ICT) and transportation, which makes it possible to easily upload various information from all over the world without filtering from cyber media.

As a form of concern and responsibility for the fate of the nation today and in the future. It is time for the government to immediately make concrete efforts that are organized, planned systematically and measurably, to take steps to re-establish national values to all components of the nation. In order to overcome the erosion of nationalism's sense of nationalism and spirit in the Indonesian generation caused by negative impacts that arise in the reform process and the negative influence of global values that are not in line with the values that exist in the Indonesian nation. The government also needs to build a spirit of optimism and provide full awareness, that irregularities in the reform process and the negative influence of global values are merely a part that cannot be avoided and must be passed in the context of the process of consolidating democracy and reinventing the social system and systems statehood in the course of the nation towards a system that is cultural, substantive and permanent. 
Efforts have been made through formal learning in schools to foster student nationalism built since elementary school. For junior high school age the civic education are not interesting and seem monotonous because they have learned it since elementary school. We need to find new solutions for unconventional learning only with the teacher. Learning by using other media that are more interesting such as video (audio visual) can be tested on junior high school students because they have advantages and abilities that we can use to overcome the limitations that exist. It is necessary to select the right media as a vehicle for channeling messages as a learning process (Kemp 1994). One of the developing media is presents audio visual methode like video.

\section{RESEARCH QUESTION}

From the point of view of the founding fathers, it was clear that the idea of Indonesian nationhood from the beginning was not intended to unite all forms of diversity and pluralism that existed in people's lives into a uniform or unified community. Local color diversity actually wants to be maintained and maintained, because it is very well realized that diversity is a local power, as well as the strength of the entire nation. It was also realized, that the nation to be born would live and live together in a single region (state), which in reality (geographic reality) is a collection of islands that are very numerous.

As President Soekarno said in his mandate at the inauguration of the National Resilience Institute at the State Palace, Jakarta, May $20^{\text {th }} 1965$ (Document of the Ministry of Information of the Republic of Indonesia), which cited the theories of Ernest Renan and Otto Bauer, "Nation" is a soul that contains the will unite and live together (the desire to live together). Nation is also a society with unity of spirit/character (Gemeninschaft Character) "Besides that, Bung Karno emphasized the importance of Geopolitics, so that not only the integrity of the nation is important, but also the integrity of the country.

Grateful for the gift of independence and Pancasila as the basis of the Indonesian state, showed a positive attitude towards the importance of civic education. In the course of the history of the Indonesian nation, the values of Pancasila in fact as a nation's view of life have been manifested in social life since before the Pancasila as the state foundation was formulated in a value system. Since ancient times, the territories in this archipelago have some values that are held firmly by the community, for example: believing in God and tolerance, mutual cooperation, deliberation, solidarity or social solidarity, and so on.

There are still many behaviors that deviate from Pancasila values, of course such behavior can be categorized as behavior that is not grateful for the independence of the Republic of Indonesia. The values of Pancasila based on the theory of causality introduced by Notonagoro (materialist causes, formalist causes, efficient causes, finalist causes), are the cause of the birth of the Republic of Indonesia national state, so that the deviation of Pancasila values can endanger the survival of the country.

The emergence of problems that plagued Indonesia shows that the values of Pancasila have been eroded in the life of society, nation and state. Therefore it is necessary to reveal various problems in this beloved country that show the importance of civic education. Need to think about learning media that are suitable for socializing Pancasila values. Are the types of conventional learning with teacher explanations effective to add insight to defending the country to students or we try to do an audio visual method that is proven effective in improving students' cognitive functions. Based on the formulation of the problem above, the research questions raised are:

1. How many influence does the teacher have on providing knowledge about civic education?

2. How many influence does the video have on providing knowledge about civic education?

3. What is the student's pretest and posttest knowledge about civic education? 


\section{THEORITICAL FRAMEWORK}

Video provides a way to channel information that is very interesting and direct (live) to users. Video is the most meaningful reference source compared to other media such as graphics, audio and so on because it is the most dynamic source or media that is effective in conveying information (Munir 2012). Furthermore, Daryanto (2010) describes video media as anything that allows audio signals to be combined with sequential moving images. In addition video programs can be combined with animation and speed settings to demonstrate changes over time. Video is a media with characteristics of ease to draw attention (mobilization of interest), speedactuality (fast in disseminating issues, news, information, etc.), differential spatial flexibility \& differential time flexibility (can be watched on location and different time), multichannel communication (communication that uses more than one channel) (Leeuwis 2004).

Several studies have proven that the use of video (audio visual media) is more effective than other learning media, such as: brochures (Sari et al. 2016), workshops (Zossou et al. 2009), farmer meetings and a day on farmer fields (Murdiyanto 2011), modules (Rahmawati et al. 2007). Further research on the effects arising from the use of audio-visual media proves that video can increase knowledge (Alif et al. 2008; Murdiyanto 2011; Sasmita HO 2015; Sari et al. 2016; Nirwana et al. 2016; Mahdalena et al. 2018), the ability to remember messages (Arsyad et al. 2015) affects attitude (Murdiyanto 2011; Mahdalena et al. 2018). The video shows openness in enhancing learning, experimentation, beliefs, beliefs and group cohesion among rural communities. Video strengthens the capacity (optimum production capacity) of more than 500 organizations and hundreds of thousands of farmers (Van Mele P 2010).

In the educational media evaluation guidebook from the Directorate General of Primary and Secondary Education (1988/1989) it was stated that the specific criteria in video assessment included aspects:

1. Material aspects

a. In accordance with the objectives formulated.

b. Easy to understand.

c. In accordance with the level of ability of students.

d. Material is presented from easy to difficult.

e. Don't use a lot of difficult words.

2. Narrative aspects
a. Sound volume is quite good.
b. Voice intonation is quite good.
c. Language style.
d. Clarity of speech.
e. Tempo greeting.

3. Visualization aspects
a. Image size.
b. Image composition.
c. Image color.
d. Image sharpness.
e. Image lighting.
f. Illustration supports images.
g. Letters are easily drawn.
h. Caption/attractive graphics.

4. Music aspects/sound effects
a. Illustration of music supports the program.
b. Sound effects support the program.
c. Music illustrations/sound effects not too loud. 


\section{Serving aspect}
a. Systematic.
b. Substitution of images is not too fast.

Learning will be more meaningful when students mentally construct representations of logical knowledge. The assumptions of cognitive theory from multimedia learning are explained by several experts then summarized by Mayer and Moreno (2002) into three, including:

1. Dual-Channel-Assumption, assumes that humans have separate channels for processing visuals (presenting images) and audio (presenting verbal messages).

2. Limited Capacity Assumption, assumes that humans can only actively process some information at one time in each channel (channel).

3. Active Processing, assume that learning will be more meaningful if students are involved in the cognition process, such as choosing relevant material, processing it into a clear picture and integrating it with existing knowledge.

Figure 1 is a cognitive theory of multimedia learning mentioned by Mayer and Moreno (2002). Narratives enter through the ear so that the communicant chooses several words for further processing in the verbal channel, arranges the sequence of words into a causal event and integrates with pre-existing visual material and knowledge. Animation enters through the eye so the communicant chooses several images to be processed further in the visual channel, arranges the series of images into a causal event and integrates with verbal material and preexisting knowledge. According to this theory, integration in one's cognition process is most likely to occur when communicants have linked the pictoral and verbal representation in working memory (memory) at the same time. In this process, supporting conditions will produce meaningful learning. This theory predicts that multimedia presentations (such as animation) tend to lead to meaningful learning rather than just presentation media.

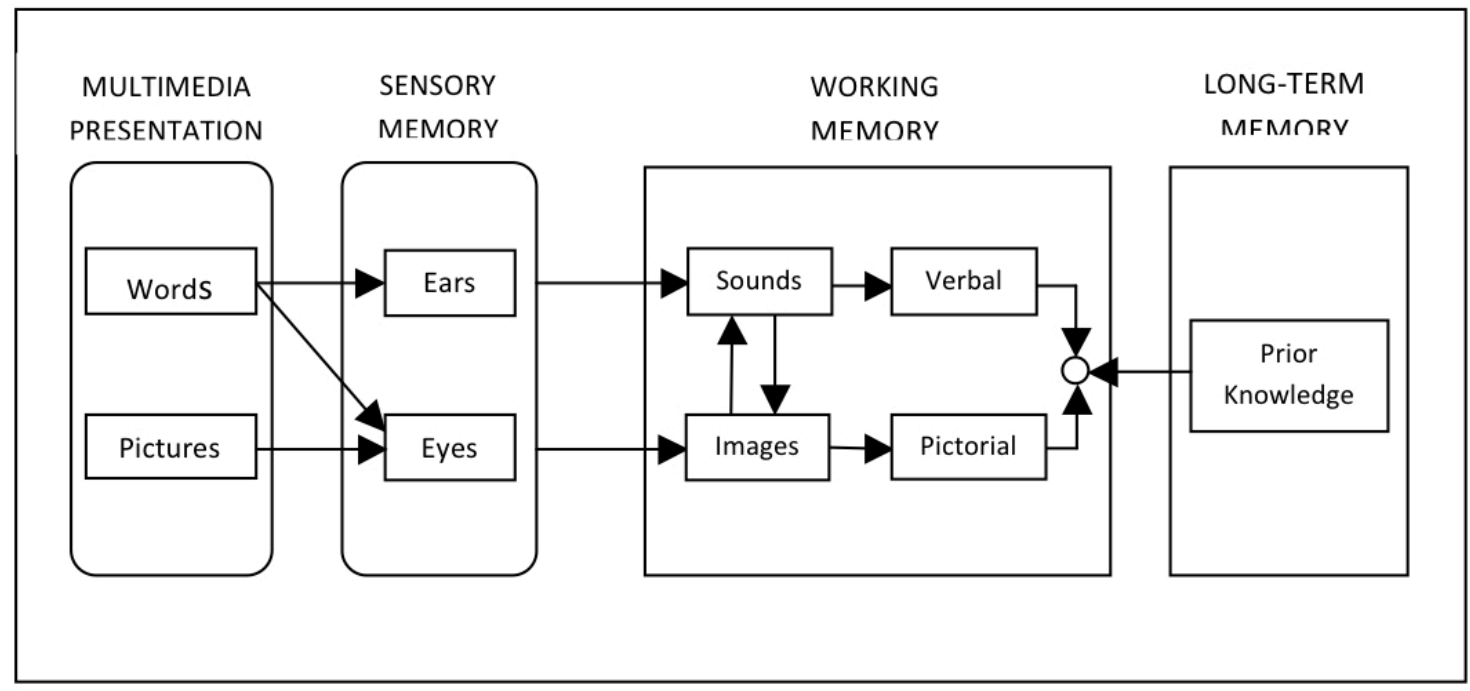

Figure 1. Cognitive Theory of Multimedia Learning (Mayer dan Moreno 2002).

Internal factors that affect one's knowledge according to Notoatmodjo (2003), include:

1. Education, in general, is all efforts planned to influence other people, individuals, groups or communities through activities to provide and increase knowledge so that they do what is expected by the educators.

2. Age, the more the age, the level of maturity and strength of a person will be more mature in thinking and working. 
3. Existing knowledge (experience), in harmony with what was revealed by Mayer and Moreno (2002) if someone already has prior knowledge about a material/object, it will be easier for him to be able to digest new knowledge related to it than those who do not have any knowledge.

External factors that affect one's knowledge according to Notoatmodjo (2003), include: (1) Economy; (2) Culture; (3) Environment.

The enthusiasm to maintain the integrity of the nation and state placed on the basis of a basic consensus, namely the Pancasila philosophy, the 1945 Constitution of the Unitary State of the Republic of Indonesia and the national motto of Unity in Diversity, must be developed and must not be extinguished. This is certainly a challenge, it can even be a threat to the existence of the Indonesian nation and state if the foundation contained in the basic consensus is either openly or secretly abandoned and ignored in the administration of the life and state of the nation.

Some important things that can be showned are:

1. Development to fill independence must be placed on the interests of all the people, nation and state, as a consequence of the implementation of the state mission mandated in the Introduction of the 1945 Constitution of the Republic of Indonesia.

2. That the emergence of various domestic turmoil is basically an indication of the existence of a sense of ownership of Indonesia by all components of the nation.

3. Along with advances in various fields of life, humans need new concepts to keep and foment the taste and spirit of nationalism and independence.

\section{Philosophical Foundation}

Pancasila as the philosophy of the Indonesian nation, is a unifying force in building national character. One character that must be built continuously is the spirit of nationality or the spirit of Indonesian unity based on the principle of tolerance, which gives birth to Unity in Diversity and provides opportunities for the development of diversity, as well as respect for the right to develop one's own culture. It is this spirit of unity that every Indonesian citizen needs to face in the face of ever-changing times.

The values of democracy are values that must be developed and extracted from the original system of life of the Indonesian nation which must underlie the social system and state system that will be built to achieve unity or nationalism now and in the future no longer on the basis of freedom, but in the form of real to fill that independence in various aspects. Rebuilding the spirit of nationalism is not easy, because it requires awareness of the attitude of life of citizens who value the values of democracy, humanity, social justice, love for the country, have legal awareness and a sense of togetherness.

\section{Juridical Platform}

National values for every Indonesian citizen, is something very strategic in facing current and future developments. The empirical reality in the field indicates that there are signs that are strong enough to break down the implementation of national values in the life of the community, nation and state. The implementation of national values in daily life is basically the spirit, enthusiasm and determination to always defend, defend and fulfill independence.

The Juridical Foundation in the context of implementing national values refers to:

1. The 1945 Constitution of the Republic of Indonesia.

2. Republic of Indonesia Law Number 39 of 1999 concerning Human Rights.

3. Republic of Indonesia Law Number 3 of 2002 concerning National Defense.

4. Law of the Republic of Indonesia Number 20 of 2003 concerning the National Education System. 
5. Government Regulation of the Republic of Indonesia Number 67 of 2006 concerning the Republic of Indonesia National Resilience Institute.

6. Republic of Indonesia Law Number 17 of 2007 concerning National Long Term Development Plans 2005 - 2025.

7. Republic of Indonesia Law Number 43 of 2008 concerning State Territory.

8. Republic of Indonesia Law Number 24 of 2009 concerning Flags, Languages and National Symbols and National Songs.

\section{Sociological Platform}

As an archipelagic country, Indonesia has diverse and diverse ethnic groups, ethnicities, races, groups, religions, languages, and cultures spread across various regions, all of which form a multicultural and pluralistic nation of society. The people of Indonesia are not only those who live in big cities with a more advanced and modern way of life, but also rural communities and border communities far from the city center and remote which are still very simple. Indonesian tribes ranging from the largest to the smallest number inhabit the land with a variety of ways and patterns of life, in accordance with the culture and traditions that are owned.

Sociologically, multicultural and pluralistic societies require recognition and appreciation across tribes and cultures. No matter how small an ethnicity is, they expect hope and recognition as social entities and as citizens of the nation. In a multicultural and pluralistic society, it is necessary to have an atmosphere of mutual respect, equality both before the law and within the government. The differences in culture, customs, and customs must be seen as the potential strength of the nation which is bound to be the real power of national unity and this has been symbolically included in the slogan of Unity in Diversity.

In the level of life of the nation and state, ethnic diversity and culture of Indonesian society must be bound in the values, norms and rules of nationality and statehood. These three levels of value are not only to maintain the nation's collectivity, but also maintain the harmony of life between national groups, but also maintain the harmony of life between community groups and between citizens. The state is obliged to socialize, internalize, and institutionalize the values, norms and institutions of life of the nation and state to citizens, and empower them to realize moral and legal awareness based on national character and identity.

In the midst of competition between nations, challenges arise both internally and externally, as a result of the increasingly open flow of information and communication. For this reason, national commitment must continue to be developed and fostered continuously and continuously to realize the love of the homeland, awareness of defending the country, and national unity, in an atmosphere of mutual respect. Unity in the diversity of cultures, customs and traditions must be nurtured and improved democratically, patterned and continuously. In this case the presence of the Civic Education is also very important.

\section{Cultural Foundation}

Cultural erosion that occurs as a reality of cultural communication which emphasizes material size or outwardly only, builds the perspective of the society that satisfaction and success are nothing but "material" as the main thing. This reasoning that prioritizes outwardly has encouraged the pattern of life of the nature of pragmatism and taken shortcuts to fulfill the desires that it wants.

Based on the above description of national values as a form of civics education is a means to educate the generation of citizens to become citizens who are aware of their rights and obligations in the context of community and state life, but also build the readiness of citizens to become citizens of the world (civil society).

\section{METHOD}


The approach used in this study is to use the experimental research method. The researcher used the experimental method because the researchers wanted to analyze the data using statistical tests on the variables. In addition, researchers also want to describe and explain the effectiveness of the treatment given (Sugiyono, 2008).

The experimental research model that will be carried out is as follows:

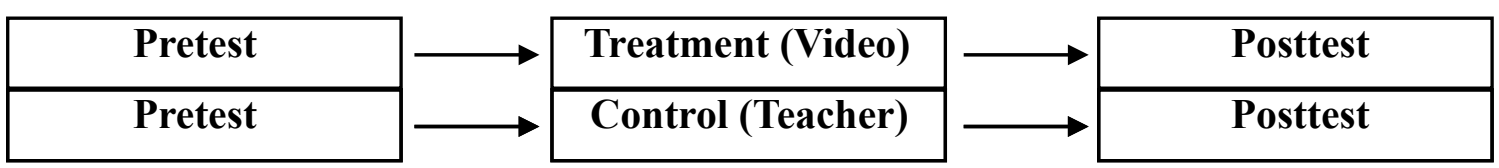

Figure 2. Experimental model with one treatment group and one control group (Stanley and Campbell, 1963).

Primary data obtained by researchers using a questionnaire with closed questions. The form of closed question questionnaire is a question that expects a short answer or expects the respondent to choose one alternative answer from each available question. Secondary data was obtained by conducting library studies obtained from reading reference books, the internet, and magazines.

In this study, we distributed questionnaires to $1^{\text {st }}$ grade of Satu Atap Lontar Junior High School students, amounting to 40 students, each of which consisted of 20 students in each group. This study also takes primary data in the form of interviews with teachers who teach Civic Education for the benefit of the material to be presented. The number of samples is adjusted to the number of students in one class. The researcher needed two classes as one treatment group as the control group. The reason for choosing this population is because junior high school students get civic subjects and they can directly practice it in their daily lives.

1. Knowledge data is carried out by formative tests to students, correct answers are worth 1 and incorrectly valued at 0 . The results of the knowledge test are interval scale and for the purposes of descriptive analysis are divided into low, medium and high categories. Low $(<6)$, medium (6-9) and high $(>9)$ categories. The level of knowledge is measured based on the understanding students have before and after the video is given with the indicators and parameters in Table 1.

Table 1. Knowledge indicators and parameters

\begin{tabular}{|l|l|}
\hline \multicolumn{1}{|c|}{ Indicators } & \multicolumn{1}{c|}{ Parameters } \\
\hline To Know & $\begin{array}{l}\text { - Knowing the line of the country of Indonesia. } \\
\text { Knowing the basic state and legal basis. } \\
\text { - Know the meaning of the Preamble of the 1945 } \\
\text { Constitution. } \\
\text { - Knowing how to implement defending the country. }\end{array}$ \\
\hline
\end{tabular}

Test the validity of each item used item analysis, which correlates the score of each item with the total score which is the number of each item score. The validity of the item is reflected in the magnitude of the correlation coefficient between item scores and the total score of the instrument. If the correlation coefficient between item scores with the total score of the instrument is positive and significant, the item can be considered valid. To calculate the correlation coefficient between the scores of the items with the total score of the instrument, the statistical formula that corresponds to the type of score of the instrument is used (Muljono, 2012). So, the Pearson correlation coefficient can be used. The author examines 15 items of 
knowledge questionnaire, then the results of the validity test show that 15 (all) questions are considered valid.

Instrument reliability test means the extent to which the results of a measurement can be trusted. Calculation of reliability will be done using the KR-20 which is assisted by Microsoft Excel as a calculation tool. The reliability value of knowledge is 0.76 and can be categorized quite reliably.

The steps that the researcher will do include:

1. Conduct literature searches for material. After getting the material, then selecting the contents (parts) that will be aired in the making of the video is assisted by the Civic Junior High School Teachers to fit the $1^{\text {st }}$ grade junior high school students' learning curriculum.

2. Making videos from pre-production, production to post-production.

3. Next, test videos and research instruments to non-respondents. Remove invalid instruments. Improve video design that is less effective.

4. Randomize the research respondents then divide them into two groups. Directing to the class that has been determined with the help of the teacher.

5. Implementation of experiments which include:

a. Give direction to the enumerator / teacher to fill out the questionnaire.

b. Direct participants to the research site.

c. Filling respondents 'characteristics is followed by measuring the initial test of the respondents' knowledge and assessment for approximately 30 minutes.

d. Material presentations by teachers in the control group and through video media for treatment groups for approximately 15 minutes.

e. Final test measurements of 30 minutes of knowledge.

Data analysis was carried out using several statistical procedures, namely:

1. Independent T-Test, also called a different test to see the difference between the experimental group and the control group. This test is not paired because the respondents in the two groups are different respondents. To see the influence between video and teacher on knowledge also seen in the significance value of the T-test.

2. Paired T-Test, also called a difference test to see the difference between the results of the initial knowledge score and the final knowledge score. This test is paired because the respondents in the two groups are the same respondents. To see the influence between video and teacher on knowledge also seen in the significance value of the T-test.

\section{RESULT AND DISCUSSION}

This study uses an experimental method which is divided into two groups, namely the experimental group (using video shows) and the control group (using the teacher) as the media used to convey the State Defense material in the Civic subjects. In Table 2 it can be seen that the average produced in all observation groups.

Table 2 Average and significance scores in the treatment and control groups

\begin{tabular}{lcc}
\hline \multirow{2}{*}{ Groups } & Pretest & Posttest \\
\cline { 2 - 3 } & Average & Average \\
\hline Treatment & 5.35 & 6.2 \\
Control & 7.65 & $9.1 *$ \\
\hline $\mathrm{p}<.05$ (significant different) $; * * \mathrm{p}<.01$ (very significant different)
\end{tabular}




\section{Initial Knowledge}

The first step in the experimental process is to analyze how the respondent's initial knowledge was measured when given treatment in both the experimental group and the control group. The students' initial knowledge before being given treatment based on Table 2 in the experimental group shows that the number 5.35 is included in the low category and the control group is 7.65 which is included in the medium category. Furthermore, it is necessary to do the Independent Sample T-Test to find out whether the differences in the respondents' initial knowledge are significant or not.

The results of the T-test showed that there was a significant difference between the experimental group and the control group because of the significance value of $.000<.05$. This illustrates that the level of knowledge between the experimental group and the control group is not homogeneous/equivalent.

The respondent's initial knowledge of State Defense in Table 3 is based on the number of respondents who answered correctly in each experimental and control group. The lowest three scores are on questions regarding the parts of the opening of the 1945 Constitution (statement item 6). Furthermore, questions regarding the values contained in the Preamble of the 1945 Constitution (statement item 8). Finally, the meaning of the Preamble of the 1945 Constitution is the second paragraph (statement item 10).

Based on Table 3, it can also be seen that some students already have knowledge about State Defense, initial knowledge is described based on the three highest scores in the experimental and control groups. Most of the respondents knew that the President was the Head of Government of the Unitary State of the Republic of Indonesia (statement item 1). Furthermore, questions about Pancasila are the basis of the state (statement item 2). Most respondents knew that defending and defending the state was the rights and obligations of all citizens (statement item 15).

Tabel 3 The number of respondents who answered correctly in each treatment group

\begin{tabular}{|c|c|c|c|c|c|c|c|c|c|c|c|c|c|c|c|}
\hline \multirow{2}{*}{ Groups } & \multicolumn{15}{|c|}{ Number of Scores in Each Item Question } \\
\hline & 1 & 2 & 3 & 4 & 5 & 6 & 7 & 8 & 9 & 10 & 11 & 12 & 13 & 14 & 15 \\
\hline Treatment & 15 & 14 & 4 & 10 & 11 & 3 & 8 & 4 & 4 & 2 & 4 & 5 & 6 & 6 & 11 \\
\hline Control & 17 & 13 & 3 & 11 & 6 & 1 & 7 & 0 & 13 & 16 & 11 & 9 & 11 & 16 & 19 \\
\hline
\end{tabular}

\section{Knowledge Enhancement}

After testing the initial knowledge of the respondents, the experimental group was given video impressions and the control group used the media teacher. Then the final knowledge test was conducted to find out whether there were differences in test scores in the experimental group and the control group. The results of the difference between the final test score and the initial test, then obtained how much the knowledge of respondents increased in the experimental and control groups.

In Table 4, it can be seen that the increase in respondents' final knowledge about State Defense can be assessed from the three highest scores of increasing knowledge in each group. In the experimental group, respondents who initially did not know the meaning of sovereignty (statement item 11) became aware of what a sovereign state was. Furthermore, the meaning of the opening paragraph of the 1945 Constitution in the third paragraph (statement item 12), the opening meaning of the fourth paragraph of the 1945 Constitution (item statement 13). Finally, the accuracy of students when answering questions about defense and defense in the state is the rights and obligations of all citizens (statement item 15). 
Table 4 Average score for increasing knowledge

\begin{tabular}{ccccccccccccccrr}
\hline \multirow{2}{*}{ Groups } & \multicolumn{11}{c}{ Increased Score for Each Item Question } \\
\cline { 2 - 16 } & $\mathbf{1}$ & $\mathbf{2}$ & $\mathbf{3}$ & $\mathbf{4}$ & $\mathbf{5}$ & $\mathbf{6}$ & $\mathbf{7}$ & $\mathbf{8}$ & $\mathbf{9}$ & $\mathbf{1 0}$ & $\mathbf{1 1}$ & $\mathbf{1 2}$ & $\mathbf{1 3}$ & $\mathbf{1 4}$ & $\mathbf{1 5}$ \\
\hline Treatment & 2 & -2 & 0 & -1 & -3 & 2 & 0 & 2 & 2 & -1 & 3 & 5 & 3 & 1 & 4 \\
Control & 2 & 2 & 12 & -10 & -1 & 0 & 11 & 1 & 2 & 2 & 4 & 5 & 7 & -8 & 0 \\
\hline
\end{tabular}

The increase in knowledge about Martial Arts in the control group was significant in some question numbers. The three highest scores for increasing knowledge are in the question of unwritten basic law called a convention (statement item 3). Furthermore, the opening of the 1945 Constitution explains the principles of the state which consist of the basis of the state, the form of the state and the objectives of the state (statement item 7). Finally, with the experimental group, students understand the meaning of the fourth paragraph of the Preamble of the 1945 Constitution (statement 13).

\section{Effects of Videos and Teachers on Knowledge Enhancement}

The first step is a data normality test because it is a requirement for unpaired T Tests. The researcher used the Shapiro-Wilk Test because the respondent's data was less than 50 . Significance showed that $.085>.005$ and $.021>.005$ so that data could be declared to be normally distributed.

The hypothesis formulated by researchers is:

$\mathrm{H} 0$ : The effect of using videos on students 'final knowledge scores is the same as the effect of teacher use on students' final knowledge scores.

H1: The effect of using videos on students 'final knowledge scores is not the same as the effect of teacher use on students' final knowledge scores.

In the results of the unpaired $\mathrm{T}$ Test, a Levene Test will appear which functions to see how the data we get assumes. The significance of the Levene Test shows that $.136>.01$ the data variance is assumed to be equal (equal). The next step is to see how the unpaired $\mathrm{T}$ test can answer the hypotheses that have been formulated. By looking at equal variances assumed the results of significance indicate that $.001<.01$ (confidence interval $=99 \%$ ) then $\mathrm{H} 0$ is rejected.

To see the effectiveness of the treatment given to two groups of classes, the mean in the experimental group (video) shows 6.2 while the average in the control group (teacher) is 9.1, it can be concluded that the control group (teacher) is more effective than the experimental group (video) with a comparison of the results of the student's final knowledge score. These results prove that, teachers in Lontar One Roof Middle School are still more dominant and effective in delivering civic material to their students than through video shows.

According to Haryoko (2009) conventional methods are oriented to mastery of material such as memorizing, in terms of mastery of material, memorizing is proven to improve learning outcomes, related to the material provided by teachers in civic subjects, mastery of material seems more than behavior or related to solving problems of daily life days, further research is needed to see whether the civic learning methods given in schools by teachers through conventional methods affect the behavior of female students, especially in the Lontar Banten Satu Atap Junior High School.

The advantages of conventional methods according to Djamarah (2010),

1. The teacher is easy to master the class, this is evidenced when students do teaching and learning activities in the classroom they are more focused on paying attention to the teacher when giving material, although there are some external disturbances from outside the classroom such as the noise of other children outside the classroom. Teachers can 
easily master the class by reprimanding students who are affected by the disorder, so they can focus on learning again.

2. Easy to organize.

3. Can be followed by a large number of students.

4. Easily prepare and implement it.

5. The teacher easily explains the lesson well.

Weaknesses of conventional methods according to Djamarah (2010)

1. Easy to become verbalism (understanding words).

2. Those who have visual properties become a loss, the greater auditives accept it.

3. If it's always used and too long, it's boring.

4. The teacher is difficult to conclude that students understand and are interested in the lecture.

5. Causes students to be passive.

\section{CONCLUSION}

The conclusions that can be given from the results of this study that both learning media both video and teacher have a positive impact on learning outcomes because it is proven to increase student knowledge. Although, in the case of students in the Lontar Satu Atap Junior High School the teacher showed more significance that significantly increased student knowledge.

Based on the results of this study, researchers can provide advice, namely the need for variations in teaching methods or new learning methods to add and facilitate the delivery of material in conventional methods that have been well done. This is to anticipate the saturation that might occur in students of Banten Lontar Satu Atap Junior High School. 


\section{REFERENCE}

Darmodiharjo, Darji. 1996. Cita Negara Integralistik Indonesia Dalam UUD 1945. BP-7 Pusat. Djamarah, Syaiful B. 2010. Strategi Belajar Mengajar. Jakarta. Asdi Mahasatya.

Hikam, Muhammad A.S. 1999. Politik Kewarganegaraan, Landasan Redemokratisasi di Indonesia. Jakarta: Penerbit Erlangga.

Kartodirjo, Sartono. 1994. Kebudayaan Pembangunan Dalam Perspektif Sejarah. Yogyakarta: Gadjah Mada University Press.

Khoiron, M. Nor, dkk. 1999. Pendidikan Politik Bagi Warga Negara (Tawaran Operasional dan Kerangka Kerja). Yogyakarta: LkiS.

Kementerian Riset, Teknologi dan Pendidikan Tinggi Republik Indonesia. 2016. Pendidikan Kewarganegaraan Untuk Perguruan Tinggi Direktorat Jenderal Pembelajaran dan Kemahasiswaaan.

Latif, Yudi. 2017. Negara Paripurna Historis, Rasionalitas dan Aktualitas Pancasila. Jakarta: PT Gramedia Pustaka Utama.

Kemp JE. 1994. Proses Perancangan Pengajaran (The Instructional Design Process). Terjemahan oleh Asril Marjohan. Bandung (ID): ITB Press.

Munir. 2012. Multimedia Konsep dan Aplikasi dalam Pendidikan. Bandung: Alfabeta.

Daryanto. 2010. Media Pembelajaran. Yogyakarta: Gava Media.

Leeuwis C. 2004. Communication for Rural Innovation, Rethinking Agricultural Extension, Third Edition. Oxford (UK): Blackwell Science.

Alif M, Nasution SH, Rohadji F. 2008. Pengaruh jenis bahasa narasi dan bentuk pesan visual video terhadap peningkatan pengetahuan tentang penyakit chikungunya pada siswa SMAN 1 Ciampea. Jurnal Komunikasi Pembangunan. 6(1):1-13.

Arsyad AA, Muljono P, Matindas K. 2015. Pengaruh durasi shot dan tempo narasi terhadap penyerapan informasi video inovasi jambu kristal. Jurnal Komunikasi Pembangunan. 13(1).

Askanius T. 2014. The Handbook of Development Communication and Social Change, First Edition. Wilkins KG, Tufte T, Obregon R, editor. New York (US): John Wiley \& Sons, Inc.

Bretz R. 1971. A Taxonomy of Communication Media. Engelwood Cliffs NJ (US): Education Technology Publications.

Campbell DT dan Stanley JC. 1963. Experimental and Quasi-Experimental Designs for Research. Boston (US): Houghton Mifflin Company.

Hamtiah S, Dwijatmiko S, Satmiko S. 2012. Efektivitas media audio visual (video) terhadap tingkat pengetahuan petani ternak sapi perah tentang kualitas susu di Desa Indrokilo Kecamatan Ungaran Barat Kabupaten Semarang. Animal Agriculture Journal. 1(2):322330.

Haryoko S. 2009. Efektivitas Pemanfaatan Media Audio-Visual Sebagai Alternatif Optimalisasi Model Pembelajaran. Jurnal Edukasi@Elektro (5)1.

Mardiyanto TC dan Prastuti TR. 2016. Efektivitas pelatihan teknologi budidaya bawang putih varietas lokal ramah lingkungan dengan metode ceramah di Kabupaten Karanganyar. [Internet]. [diunduh 2017 Mei 28 pukul 12:00]. Tersedia pada: journal.umy.ac.id/index.php/ag/article/download/1133/1211

Mayer RE dan Anderson RB. 1991. Animations need narrations: an experimental test of a dualcoding hypothesis. Journal of Educational Psychology. 83(4):484-490.

Mayer RE dan Anderson RB. 1992. The instructive animation: helping students build connections between words and picture in multimedia learning. Journal of Educational Psychology. 84(4):444-452. 
Mayer RE dan Moreno R. 2002. Animation As An Aid to Multimedia Learning. Educational Psychology Review. 14(1):87-99.doi:10.1023/A:1013184611077

Moestofa. 2015. Model pembelajaran generatif melalui media animasi berbasis Flash dan video ditinjau dari keterampilan generik dan keingintahuan. Bioedukasi. 8(1):23-27.

Morissan. 2007. Periklanan : Komunikasi Pemasaran Terpadu. Jakarta (ID): Ramdina Prakarsa.

Muljono P. 2012. Metodologi Penelitian Sosial. Bogor (ID): IPB Press.

Murdiyanto E. 2011. Efektivitas penyuluhan pada PT. Takii Seed terhadap petani kool di Desa Pikatan, Kecamatan Wonodadi, Kabupaten Blitar. Jurnal Sosial Ekonomi Pertanian dan Agribisnis. 8(1):42-49.

Nisfiannoor M. 2009. Pendekatan Statistika Modern untuk Ilmu Sosial. Jakarta (ID): Salemba Humanika.

Nugroho E. 2009. Pemanfaatan aplikasi multimedia sebagai sarana penyebarluasan informasi dan penyuluh pertanian. Di dalam: Seminar Nasional "Kebijakan Aplikasi Teknologi Informasi dan Komunikasi untuk Peningkatan Daya Saing Agribisnis Indonesia" Himpunan Informatika Pertanian Indonesia. Prosiding Seminar Nasional Himpunan Informatika Pertanian Indonesia [Internet]. [2009 Agu 6-7; Bogor, Indonesia]. Bogor (ID): IPB. hlm 1-7; [diunduh 2016 Nov 2 pukul 13:34]. Tersedia pada: http://repository.ipb.ac.id/handle/123456789/31466

Nurfathiyah dan Suratno. 2011. Pengaruh visualisasi gerak dan foto pada media video terhadap peningkatan pengetahuan di Desa Tangkit Baru. Jurnal Penelitian Universitas Jambi Seri Sains. 13(1):43-52.

Nurfathiyah. 2014. Pengaruh penggunaan ilustrasi dan bahasa pada media buklet terhadap peningkatan pengetahuan petani di Kabupaten Muara Jambi. Jurnal Penelitian Universitas Jambi Seri Sains. 16(1):53-70.

Sari RY, Yulida R, Sayamar E. 2016. Perbandingan tingkat pengetahuan petani sebelum dan sesudah menggunakan media visual dan media audio-visual terhadap petani di Kelurahan Telaga Samsam Kecamatan Kandis Kabupaten Siak. Jurnal Online Mahasiswa (JOM) Faperta. 3(1):1-10.

Sasmita HO. 2015. Pengaruh bentuk visualisasi dan format narasi video terhadap peningkatan pengetahuan tentang pengolahan yogurt rumahan [Tesis]. Bogor (ID): Institut Pertanian Bogor.

Vaughan T. 2004. Multimedia: Making it Work, Edisi Keenam. Penerbit Andi, penerjemah. Yogyakarta: Andi Offset.

Zossou E, Van Mele P, Vodouhe SD, Wanvoeke J. 2009. The power of video to trigger innovation: rice processing in central Benin. International Journal of Agricultural Sustainability. 7(2):119-129.doi:10.3763/ijas.2009.0438

Zossou E, Van Mele P, Vodouhe SD, Wanvoeke J. 2010. Women groups formed in response to public video screenings on rice processing in Benin. International Journal of Agricultural Sustainability. 8(4):270-277.doi:10.3763/ijas.2010.0499

Zossou E, Van Mele P, Wanvoeke J, Lebailly P. 2012. Participatory impact assessment of rice parboiling videos with women in Benin. Expl Agric. 48(3):438447.doi:10.1017/S0014479712000117 